\title{
Hubungan Pemerintah Daerah dengan DPRD Kabupaten Kuantan Singingi dalam Penetapan APBD Tahun 2017
}

\author{
${ }^{1}$ Fhisilmi Kaffah, ${ }^{2}$ Zulfa Harirah MS \\ ${ }^{1}$ Universitas Riau, Indonesia; fhisilmianwar@gmail.com \\ ${ }^{2}$ Universitas Riau, Indonesia; zulfaharirahms@lecturer.unri.ac.id
}

\begin{abstract}
Determination of the budget and regional expenditure income (APBD) of Kuantan Singingi Regency has a polemic in the formulation process. The delay in the enactment of this regional budget regulation indicates that there is a bad relationship between the regional head and the Kuantan Singingi district parliament. To answer the problems that occur, an analysis is conducted to find the bright spots of the polemic. This research was conducted to see the relationship between the DPRD and local government in the process of formulating the APBD. This research uses a qualitative approach. Data collection techniques namely by studying literature and using previous research. This study uses Stone's interaction type theory, namely decisional type, anticipated reaction type, non-decisional making type, systemic type. The results showed that the relationship between the local government and the Regional Parliament of Kuantan Singingi in the formulation of the 2017 Regional Budget was included in the type of non-decessional making interaction. This type of interaction is a form of interaction that is influenced by the presence of a strong majority group in influencing the process of formulating the APBD, especially on the submission and agreement of the KUA-PPAS by providing public issues so that a bad image is formed.
\end{abstract}

Keywords: Good Government, Local Government, Decentralization, Coordination, Public Expenditure

\section{Pendahuluan}

Penyelenggaraan pemerintahan daerah di Indonesia dilakukan berdasarkan otonomi daerah dengan asas desentralisasi. Unsur penyelenggara pemerintahan daerah yaitu kepala daerah dan dewan perwakilan rakyat daerah. Penyelenggaraan pemerintahan daerah yang dilaksanakan oleh kepala daerah untuk menjalankan fungsi pelaksanaan peraturan daerah dan kebijakan yang telah dibuat berkaitan lansung dengan dewan perwakilan rakyat daerah (daerah) yang mempunyai fungsi pembentukan perda, anggaran dan pengawasan. Keterkaitan fungsi yang sangat signifikan antara kepala daerah dengan DPRD dalam pembuatan legislasi daerah yaitu perda. Perda yang berperan penting untuk daerah dalam setiap tahun yaitu perda mengenai anggaran pendapatan dan belanja daerah (APBD).

Pengelolaan keuangan pemerintahan daerah mendorong dan memperhatikan kepentingan rakyat. Pengelolaan kekuangan yang diharapkan terjadi yaitu pengelolaan yang transparan, partisipatif, dan akuntabel. Salah satu tugas kepala daerah yaitu menyusun dan mengajukan rancangan perda tentang APBD, rancangan perda tentang perubahan APBD, dan rancangan perda tentang pertanggungjawaban pelaksanaan APBD kepada DPRD untuk dibahas Bersama.

Pengelolaan keuangan daerah merupakan bagian yang tidak terpisahkan dari penyelenggaraan urusan pemerintahan yang menjadi kewenangan daerah sebagai akibat dari penyerahan urusan pemerintahan. Pengelolaan keuangan daerah dilakukan secara tertib, taat pada ketentuan peraturan perundang-undangan, efisien, ekonomis, efektif, transparan, ddan bertanggung jawab dengan memperhatikan rasa keadilan, kepatuhan, dan manfaat untuk masyarakat. 
Keuangan daerah adalah semua hak dan kewajiban daerah dalam rangka penyelenggaraan pemerintahan daerah yang dapat dinilai dengan uang. Bentuk pengelolaan keuangan daerah diimplementasikan kedalam APBD (rencana kekuangan tahunan daerah yang ditetapkan dengan perda). Azas umum APBD yaitu disusun sesuai kebutuhan dan penyelenggaraan Pemerintah Daerah; berpedoman pada RKPD dalam rangka mewujudkan pelayanan kepada masyarakat; mempunyai fungsi otorisasi, perencanaan, pengawasan, alokasi, distribusi, dan stabilisasi; ditetapkan dengan perda.

Penyusunan APBD memiliki prinsip yaitu sesuai dengan kebutuhan penyelenggaraan pemerintahan daerah berdasarkan urusan dan kewenangannya; tertib, taat pada ketentuan perundang-undangan ekonomis, efektif, transparan, dan bertanggung jawab dengan memperhatikan rasa keadilan, kepatuhan, dan manfaat untuk masyarakat; tepat waktu; transparan; partisipatif; dan tidak bertentangan dengan kepentingan umum, peraturan yang lebih tinggi dan peraturan daerah lainnya.

Salah satu prinsip dalam penyusunan dan penetapan APBD yaitu tepat waktu, yang mana ada jadwal dalam setiap tahapan dalam proses penyusunan APBD tersebut. Proses final dan penyusunan APBD yaitu penetapan peraturan daerah tentang APBD dan peraturan kepala daerah tentang penjabaran APBD sesuai dengan hasil evaluasi batas waktunya paling lambat akhir Desember. Apabila penetapan Perda APBD yang dilakukan oleh kepala daerah dan DPRD tidak sesuai waktu maka akan dikenai sanksi adminitratif sesuai dengan UU No 23 Tahun 2014. Tentunya hal ini sangat merugikan masyarakat untuk meningkatkan kesejahteraan masyarakat dan keberlangsungan pembangunan di suatu daerah.

Kabupaten Kuantan Singingi merupakan kabupaten di Provinsi Riau yang tergolong terlambat dalam menetapkan dan mengesahkan APBD-nya pada tahun 2017 dan disahkan pada 05 Mei 2017. Permasalahan penetapan APBD Kuantan Singingi tidak tepat waktu dan memiliki polemik setelah Pilkada dilaksanakan. Hal ini dikarenakan DPRD yang tidak menyetujui rencana anggaran yang diajukan oleh Pemerintah Daerah Kabupaten Kuantan Singingi.

Tabel 1

Jadwal Waktu Penetapan APBD Kuantan Singingi

\begin{tabular}{lll}
\hline No. & Tahun & \multicolumn{1}{c}{ Waktu } \\
\hline $\mathbf{1}$ & APBD tahun 2016 & 31 Desember 2015 \\
\hline $\mathbf{2}$ & APBD tahun 2017 & 05 Mei 2017 \\
\hline $\mathbf{3}$ & APBD tahun 2018 & 30 November 2017 \\
\hline $\mathbf{4}$ & APBD tahun 2019 & 30 Novermber 2018 \\
\hline $\mathbf{5}$ & APBD tahun 2020 & 30 November 2019 \\
\hline
\end{tabular}

Sumber: Sekretariat DPRD Kabupaten Kuantan Singingi, 2020

Keterlambatan pengesahan Perda APBD ini mengindikasikan adanya hubungan yang tidak baik antara kepala daerah dengan DPRD kabupaten Kuantan Singingi. Menurut bupati Kuantan Singingi, keterlambatan pengesahan APBD Kuantan Singingi karena keterlambatan penyusunan rencana pembangunan jangka menengah daerah (RPJMD) dan ditambah tidak adanya rencana pembangunan jangka Panjang (RPJP) Kuantan Singingi. Namun pastinya ada faktor lain penyebab terlambatnya pengesahan APBD Kabupaten Kuantan Singingi tahun 2017. 
Keterlambatan penetapan APBD akan berdampak pada terhambatnya pembangunan ekonomi di Kabupaten Kuantan Singingi. Keterlambatan Kabupaten Kuantan Singingi dalam mengesahkan APBD tahun 2017 terjadi hingga bulan April. Keterlambatan dalam penetapan APBD juga akan menjadi patologi legislasi yang akan menganggu pembangunan daerah dan ekonomi masyarakat. Pembangunan di daerah menjadi tidak efektif dan tidak efisien.

Proses penetapan APBD adalah proses politik dengan tahapan yang cukup rumit dan mengandung nuansa politik yang cukup tinggi, dimana terjadi proses tawar menwar antara eksekutif dan legislatif, serta merupakan pencerminan kekuatan relatif dari berbagai pihak yang terlibat dalam proses tersebut, yang masing-masing memiliki kepentingan berbeda terhadap APBD tersebut. Dinamika politik yang terjadi mengakibatkan Tarik-menarik kepentingan antara kepala daerah dan DPRD, yang akhirnya memperlambat proses penetapan ranperda APBD menjadi APBD.

Ada banyak tulisan mengenai hubungan kepala daerah dan dewan perwakilan rakyat daerah di Indonesia dalam artikel-artikel ilmiah sebelumnya. Wance (2017) kajiannya yaitu melihat pola relasi eksekutif dan legislatif pada penyusunan legislasi daerah pada pembahasan APBD Kabupaten Buru Selatan 2015. Wance melihat ada tiga pola interaksi (akomodasi, dominasi,kompromi) dan ada pola interaksi decisional atau pertentangan pada perumusan KUA dan PPAS yang disebabkan oleh personal background dan political background. Melki (2018) melihat hubungan DPRD dan pemerintahan daerah dalam penetapan anggaran pendapatan dan belanja daerah dengan menggunakan penelitian yuridis normatif yaitu Undang-Undang Nomor 9 Tahun 2015. Melki melihat hubungan Pemerintah Daerah dan DPRD cenderung berhadapan secara diametral sesuai kedudukan tugas dan wewenang.

Kemudian Nawawi (2015) melihat hubungan DPRD dan Pemerintah Daerah dalam pembuatan kebijakan kemiskinan di Provinsi Sulawesi Barat. Nawawi melihat dalam pembuatan perda hubungan yang terbentuk adalah diametral. Wance (2017) dalam artikelnya mengenai politik anggaran eksekutif dan legislative pada pembahasan APBD Kabupaten Buru Selatan. Dari penelitan Wance, maka terlihat terjadi pola interaksi decisional yang mengakibatkan keterlambatan penetapan APBD dan pada penetapan APBD tahun berikutnya terbentuk pola relasi anticipated reaction.

Artikel yang saya tulis ini akan melihat dari sisi lain baik yaitu sisi kewenangan dan politis antara kepala daerah dan DPRD kabupaten Kuantan singing dalam penetapan dan pengesahan APBD Kuantan singing tahun 2017. Penulis juga akan melihat faktor penyebab keterlambatan pengesahan APBD dan personal background serta political background kepala daerah dan pimpinan DPRD sehingga terbentuknya hubungan yang haromins atau tidak harmonis antara Kepala Daerah dan DPRD.

\section{Metode Penelitian}

Penelitian ini merupakan penelitian kualitatif. Pengumpulan data dilakukan melalui studi literatur terhadap jurnal dan media massa. Teknik analisa data dilakukan melalui reduksi,pengorganisasin data dan analisis data. Teori yang digunakan dalam tulisan ini adalah tipe interaksi. Bentuk hubungan positif dan negatif, menurut Stone dalam Annas (2017) dapat dipetakan menjadi beberapa tipe interaksi sebagai berikut:

1. Tipe decesional, adalah interaksi yang terbentuk karena penggunaan kekuasaan dan wewenang yang dimiliki oleh masing-masing kelompok yang terlibat untuk memperjuangkan kepentingannya atau dalam konteks keputusan (kebijakan) adalah untuk menetapkan pilihan-pilihan akhir. Interaksi ini juga dapat terjadi karena adanya 
kelompok kepentingan seperti bisnis yang secara lansung memberikan dukungan kepada pihak atau kelompok tertentu seperti pada saat pemilihan umum atau kampanye.

2. Tipe anticipated reaction, adalah interaksi yang bersifat lansung namun yang terbentuk karena struktur kekuasaan dan penguasa atas sumber daya pada situasi tertentu. Dapat terjadi jika Pemerintah Daerah berupaya mengakomodir keinginan DPRD sepanjang hal tersebut memberikan manfaat kepada pemerintah karena jika tidak, dilaksanakan reaksi DPRD akan berdampak pada terhambatnya kebijakan.

3. Tipe non-decision making, adalah interaksi yang diidentifikasi adanya kelompok yang kuat atau mayoritas berupaya mempengaruhi kebijakan. Interkasi tipe ini juga dapat melibatkan pihak ketiga atau eksternal untuk mendukung salah satu aktor keputusan. Pengaruh eksternal ini menjadi bagian dari kekuasaan atau kepentingan elit. Dalam konteks ini dapat terjadi misalnya pemerintahan daerah karena lebih mempunyai sumber daya dapat mempengaruhi pengambilan kebijakan.

4. Tipe systemic, adalah interaksi yang tidak secara lansung dipengaruhi oleh sistem, seperti sistem politik, ekonomi, sosial. Hal ini diidentifikasi melalui perilaku elit pejabat yang berpihak terhadap dirinya sendiri. Hal ini diidentifikasi melalui perilaku elit atau pejabat yang berpihak kepada kelompok kepentingan tertentu. Dalam tipe interaksi ini penggunaan kekuasaan dilakukan oleh tiga kelompok atau aktor yang menempatkan pejabat publik dalam posisi tengah. Interaksi tidak langsung ditandai terjadinya interaksi antara kelompok kepentingan yang berusaha untuk mempengaruhi elit kebijakan dengan tujuan agar kepentingannya dapat menjadi pilihan kebijakan, namun di satu sisi, penggunaan dukungan kelompok kepentingan dinilai strategis oleh elit kebijakan untuk memperkuat prioritas pilihan kebijakannya.

\section{Hasil Dan Pembahasan}

\section{Proses Penetapan APBD}

Pemeritahan di daerah dapat terselenggara karena adanya dukungan faktor sumber daya yang mampu menggerakkan jalannya roda organisasi pemerintahan dalam rangka pencapaian tujuan daerah. Faktor keuangan merupakan faktor utama yang merupakan sumber daya finansial bagi pembiayaan penyelenggaraan roda pemerintahan daerah. Kebijakan keuangan daerah senantiasa diarahkan pada tercapainya sasaran pembangunan, yakni terciptanya perekonomian daerah yang mandiri sebagai usaha bersama atas asas kekeluargaan berdasarkan demokrasi ekonomi yang berlandaskan Pancasila dan Undang-Undang Dasar 1945 dengan peningkatan kemakmuran rakyat yang merata. Keuangan daerah menyangkut keseluruhan tatanan, perangkat, kelembagaan, dan kebijakan penganggaran yang meliputi pendapatan dan belanja daerah (Tangkilisan, 2005).

APBD merupakan salah satu komponen penting dalam keuangan daerah yang melibatkan eksekutif dan legislatif lebih intim. Proses penetapan APBD merupakan hasil kesepakatan antara pihak eksekutif dalam hal ini Pemerintah Daerah dan pihak legislatif yang dalam hal ini adalah pihak DPRD. Jika dilihat dari teori keagenan (Bergman dan Lane dalam Amin, 2019), pihak eksekutif dapat diidentifikasi sebagai agen sedangkan pihak legislatif sebagai principal, yang diantara keduanya telah terjadi kesepakatan atau pembuatan kontrak.

Permasalahan yang sering terjadi yaitu hubungan diametral antara eksekutif dan legislatif menjadikan pola hubungan konflik antara eksekutif dan legislatif yang menyebabkan Tindakan-tindakan tidak produktif. Selain itu legislatif sebagai principal bagi eksekutif memunculkan perilaku opportunistik legislatif untuk merealisasikan kepentingannya. 
Jika eksekutif dan legislatif sama-sama mengutamakan kepentingan pribadi atau golongannya sendiri (self-interest). Self-interest dari pihak eksekutif timbul karena keunggulannya dalam hal penguasaan informasi dibandingkan legislatif. Keunggulan ini bersumber dari kondisi factual bahwa eksekutif adalah pelaksana semua fungsi pemerintahan daerah dan berhubungan dengan masyarakat dalam waktu yang lama. Sedangkan self-interest, dari pihak legislatif karena adanya discretionary power yang dimiliki sehingga dalam proses penyusunan anggaran cenderung mengutamakan kepentingannya untuk menjaga kesinambungan jabatannya (Syarif dalam Amin, 2019).

Menurut Lijphart dalam Heryanto (2018), pola hubungan eksekutif dan legislatif itu ditandai dengan dua kecenderungan. Pertama, pola relasi yang mendominasi, misalnya dominasi eksekutif terhadap legislatif maupun sebaliknya. Kedua, relasi yang menekankan pada keseimbangan kekuasaan di antara eksekutif dan legislatif. Hubungan antara Pemerintah Daerah dan DPRD merupakan hubungan kerja yang kedudukanya setara dan bersifat kemitraan. Kedudukan yang setara berarti bahwa diantara Lembaga pemerintahan daerah itu memiliki kedudukan yang sama dan sejajar, artinya tidak saling membawahi. Hubungan kemitraan bermakna bahwa antara Pemerintah Daerah dan DPRD adalah sama-sama mitra sekerja dalam membuat kebijakan daerah untuk melaksanakan otonomi daerah sesuai dengan tugas dan fungsi masing-masing sehingga kedua Lembaga itu membangun suatu hubungan kerja yang sifatnya saling mendukung bukan merupakan lawan ataupun pesaing satu sama lain dalam melaksanakan tugas dan fungsi masing-masing.

Proses penetapan APBD di suatu pemerintahan daerah, sebelum dilakukan penyusunan APBD terlebih dahulu dibuat kesepakatan antara eksekutif dengan legislatif tentang arah dan kebijakan umum serta prioritas anggaran yang akan menjadi pedoman dalam penyusunan APBD. Pihak eksekutif membuat rancangan APBD yang kemudian diserahkan kepada legislatif untuk dipelajari dan dibahas Bersama-sama sebelum ditetapkan sebagai peraturan daerah. Dalam perspektif keagenan ini merupakan bentuk kontrak yang menjadi alat bagi legislatif untuk mengawasi pelaksanakan anggaran oleh eksekutif.

Sedangkan dari sisi legislatif, juga muncul self-interest dimana legislatif mengutamakan kepentingan pribadi atau kelompoknya dengan mengusakan agar kepentingannya terakomodir dalam APBD walaupun terkadang kegiatan atau programnya tidak sesuai dengan kebijakan umum anggaran atau PPAS yang telah disepakati sebelumnya. Hal ini untuk menjaga nama baik mereka dan usaha untuk menepati janji-janji yang sudah diutarakan kepada konstituennya.

Permasalahan yang sering terjadi dalam penetapan APBD adalah keterlambatan dalam penetapan atau pengesahan. Hal ini berdampak pada proyek-proyek pembagunan yang pasti akan terhambat. Permasalahan keterlambatan pengesahan APBD juga berkaitan dengan proses penyusunan RKPD yang memiliki kendala. Hal ini dikarenakan anggota DPRD menganggap bahwa musrenbang hanyalah proses normatif dan menjadi kewenangan eksekutif atau Pemerintah Daerah. Dampak yang diakibatkan dalam tahap penganggaran ini adalah terjadinya proses yang Panjang dan menyita waktu pada saat pembahasan KUA, PPAS maupun pada saat pembahasan RAPBD dikarenakan adanya penambahan kegiatan-kegiatan yang dilakukan anggota DPRD untuk menampung aspirasinya.

Di samping itu, pada tahap proses penyusunan KUA dan PPAS, penyusunan RAPBD dan proses penetapan APBD umumnya juga mengalami berbagai kendala. Berdasarkan Permendagri No. 13 Tahun 2006, penandatangan rancangan KUA dan PPAS antara kepala daerah dan DPRD paling lambat dilakukan pada akhir bulan Juli sebelum tahun anggaran yang bersangkutan dilaksanakan. Namun praktik yang terjadi nota kesepakatan tersebut ditandatangani tidak sesuai dengan ketentuan yang ada. Keterlambatan penandatangan nota 
kesepakatan tersebut disebabkan karena penyampaian rancangan KUA-PPAS kepada DPRD sering terlambat. Faktor yang menyebabkan keterlambatan tersebut yaitu:

1. Banyaknya kepentingan dari pihak eksekutif dalam penyusunan rancangan KUAPPAS

2. Kurangnya komitmen eksekutif dalam menaati jadwal penyusunan APBD

3. Adanya peraturan tentang pedoman penyusunan APBD dari pemerintah pusat yang berubah dan terbit setiap tahun

4. Penerbitan peraturan terkait dana dari pemerintah pusat yang terlambat dan berubah-ubah.

Setelah rancangan KUA-PPAS selesai disusun oleh Pemerintah Daerah, selanjutnya disampaikan kepada DPRD. Pada saat pembahasan rancangan KUA-PPAS di rapat badan anggaran DPRD sering mengalami kendala ketidaktepatan waktu pembahasan sebagai akibat dari pesyaratan kehadiran anggota banggar DPRD yang tidak terpenuhi (menunggu quorum). Kurangnya komitmen kehadiran legislatif dan ketidakjelasan hubungan antara program kegiatan dalam PPAS dalam mendukung kebijakan anggaran di KUA menjadikan pembahasan memakan waktu yang lama.

Dalam proses pembahasan baik eksekutif maupun legislatif melakukan penambahan dan pengurangan terhadap program kegiatan yang tercantum dalam RAPBD, bahkan penambahan tersebut tidak sesuai dengan KUA-PPAS tanpa persetujuan TAPD. Hal ini bertentangan dengan ketentuan yang mengaturnya. Komitmen eksekutif untuk menaati jadwal penyusunan APBD tidak lepas dari sikap eksekutif yang lebih mengutamakan kepentingannya. Selain eksekutif yang memiliki pengetahuan dalam pemahaman birokrasi, administrasi, dan peraturan-peraturan yang mendasari aspek pemerintahan menyebabkan shocked anggaran.

Dalam proses penetapan APBD tahun 2017 Kabupaten Kuantan Singingi yang terlambat dan memiliki polemik makas penulisan akan mengidentifikasi dari hubungan Pemerintah Daerah dan DPRD. Untuk melihat hubungan DPRD dan Pemerintah Daerah Kabupaten Kuantan Singingi dalam penetapan APBD yang memiliki polemik sejak penetapan APBD tahun 2017 hingga sekarang ada hubungannya dengan Pilkada yang berlansung pada tahun 2015. Bupati dan Wakil Bupati yang menang partainya berlawanan dengan mayoritas ketua dan anggota DPRD Kabupaten Kuantan Singingi. Hal ini dapat dilihat dari susunan anggota DPRD Kabupaten Kuantan Singingi peridoe 2014-2019 dan susunan partai pengusung pasangan calon Bupati dan Wakil Bupati Kabupaten Kuantan Singingi pada Pilkada 2015.

Tabel 2

Nama Anggota DPRD Kabupaten Kuantan Singingi Periode Tahun 2014-2019

\begin{tabular}{|c|c|c|c|}
\hline No & Nama anggota & No & Nama anggota \\
\hline 1 & Andi Putra (Golkar/Incumbent) & 19 & Adam (Golkar) \\
\hline 2 & Muslim (Golkar/Incumbent) & 20 & Sastra Febriawan (Golkar) \\
\hline 3 & $\begin{array}{lc}\text { Jons } & \text { Ade } \\
\text { (Golkar/Incumbent) }\end{array}$ & 21 & Asnidar (Golkar) \\
\hline 4 & Alhamra (Gerindra) & 22 & Solehudin (Gerindra) \\
\hline 5 & Weri Naldi (Demokrat) & 23 & Musliadi (PKB/ Incumbent) \\
\hline 6 & Rustam Effendi (Nasdem/ Incumbent) & 24 & Jefri Antoni (Demokrat) \\
\hline
\end{tabular}




\begin{tabular}{clcl}
\hline $\mathbf{7}$ & Darmizar (PPP/incumbent) & 25 & Maspar Mahmur (PAN) \\
\hline $\mathbf{8}$ & Raden (PKPI/incumbent) & 26 & Mutiara (PBB/ Incumbent ) \\
\hline $\mathbf{9}$ & Rino Elpino (PBB) & 27 & Rosi Atalia (Hanura) \\
\hline $\mathbf{1 0}$ & Andi Nurbai (PAN/incumbent) & 28 & Sarjan. M (nasdem) \\
\hline $\mathbf{1 1}$ & Komperensi (Golkar/ Incumbent) & 29 & Mustafa Sailillah (PPP) \\
\hline $\mathbf{1 2}$ & Sutoyo (Golkar) & 30 & Andi Cahyadi (Golkar/Incumbent) \\
\hline $\mathbf{1 3}$ & Jon Tikal (Demokrat/ Incumbent) & 31 & Hamzah Alim (PAN) \\
\hline $\mathbf{1 4}$ & Pangestuti (Gerindra) & 32 & Sardiyono (PPP/Incumbent) \\
\hline $\mathbf{1 5}$ & Naswan (PPP/Incumbent) & 33 & Agus Samad (PBB/Incumbent) \\
\hline $\mathbf{1 6}$ & Warsono (PKB) & 34 & Erdizal (PKB) \\
\hline $\mathbf{1 7}$ & Ahmad Mukhlis (Hanura) & 35 & Andhy Manzauri (Nasdem) \\
\hline $\mathbf{1 8}$ & Maruli Tamba (PDIP) & & \\
\hline Sumb & Kuansing torkini & & \\
\hline
\end{tabular}

Sumber; kuansing terkini http://kuansingterkini.com/berita/detail/4625/2014/09/08/dilantikketua-pn,-35-anggota-dprd-kuansing-periode-2014-2019-resmi-bertugas

Tabel 3

Pasangan Calon Bupati dan Wakil Bupati Kabupaten Kuantan Singingi Tahun 2015 dan Partai Pendukung

\begin{tabular}{lll}
\hline \multicolumn{1}{c}{$\begin{array}{c}\text { No } \\
\text { urut }\end{array}$} & Pasangan calon & Partai Pendukung \\
\hline $\mathbf{1}$ & Indra Putra, ST - Komperensi, SP, M.Si & - PAN \\
& & - Partai demokrat \\
& & - Partai NasDem \\
& & - Partai Hanura \\
\hline $\mathbf{2}$ & Drs.H.Mursini, M.Si - H.Halim & - PPP \\
& & - Partai gerindra \\
& & - PDIP \\
\hline $\mathbf{3}$ & Ir.H.Mardjan Utsha, MM - Muslim, S.Sos., M.Si & - PKB \\
& & - PBB \\
& & - PKPI \\
\hline
\end{tabular}

Sumber: KPU.go.id https://pilkada2015.kpu.go.id/kuantansingingikab

Maka, dapat dilihat dari jumlah anggota DPRD Kabupaten Kuantan Singingi periode tahun 2014-2019 yang berasal dari partai pendukung pasangan Mursini-Halim hanya 7 orang. Maka persentasenya di DPRD yaitu 20\%. Sisanya adalah yang berasal partai oposisi yang menjadi lawan Bupati dan Wakil Bupati Kuantan Singingi pada Pilkada tahun 2015. Hal ini mengindikasikan lemahnya kekuatan Pemerintah Daerah jika berhadapan dengan legislatif (DPRD). 


\section{Interaksi Pemerintah Daerah dan DPRD Kabupaten Kuantan Singingi dalam Penetapan APBD tahun 2017}

Untuk melihat bagaimana hubungan Pemerintah Daerah dan DPRD kabupaten Kuantan singini, penulis menggunakan tipe interaksi kekuasaan menurut Stone.

\section{Tipe Decisional}

Tipe decisional adalah interaksi yang terbentuk karena penggunaan kekuasaan dan wewenang yang dimiliki oleh masing-masing kelompok yang terlibat untuk memperjuangkan kepentingannya atau dalam konteks keputusan (kebijakan). Dalam memperjuangkan kepentingan masing-masing pihak, maka dapat dilakukan dengan cara tawar menawar untuk mengakomodasi kepentingan Pemerintah Daerah dan DPRD dalam proses penetapan APBD. Berbagai cara yang dapat dilakukan DPRD salah satunya adalah menunda jadwal persidangan.

Dari hasil wawancara yang didapat dari penelusuran berbagai sumber mengenai keterlambatan pengesahan APBD tahun 2017 Kabupaten Kuantan Singingi dalam perumusannya menggunakan kekuatan wewenang masing-masing dalam perumusan APBD tahun 2017. Penggunaan wewenangpun dipengaruhi oleh kepentingan politik. Bupati periode 2016-2021 dilantik pada 01 Juni 2016, sedangkan seharusnya menurut ketentuan penyusuna APBD, pada akhir Mei telah dilakukan penyusunan RKPD. Namun setelah dilantik, Pemerintah Daerah masih sibuk berbenah untuk memulai pemerintahan.

Di lain hal, DPRD dengan mayoritas anggota yang berasal dari partai oposisi pada Pilkada Kuantan singingi tahun 2015 terus mendesak Pemerintah Daerah untuk menyerahkan KUA-PPAS. Keinginan DPRD ini tidak dapat terlaksana, karena pada kenyataanya Kabupaten Kuantan Singingi belum memiliki RPJPD dan RPJMD. Ketua komisi C DPRD Kuasning yang berasal dari partai oposisi menyatakan DPRD sudah menyurati Bupati Kabupaten Kuantan Singingi untuk segera menyerahkan draft KUA-PPAS, namun permintaan DPRD ini sepertinya kurang dipedulikan.

Perbedaan pernyataan tersebut mengindikasikan bahwa kurang baiknya komunikasi antara eksekutif dan legislatif sehingga masing-masing pihak menggunakan kewenangan yang ada untuk memperjuangkan kepentingannya. Pada dasarnya, penyampaian KUA-PPAS harusnya dilakukan pada pertengahan Juni dan disepakati pada akhir Juli. Permasalahan ini membuat adanya hubungan yang tidak baik antara Pemerintah Daerah dan DPRD sehingga terbentuknya citra buruk dari salah satu pihak yang mengindikasikan tidak harmonisnya hubungan Pemerintah Daerah dan DPRD.

\section{Tipe Anticipated Reaction}

Tipe anticipated reaction adalah interaksi yang dapat terjadi jika Pemerintah Daerah berupaya mengakomodir keinginan DPRD sepanjang hal tersebut memberikan manfaat kepada pemerintah karena jika tidak, dilaksanakan reaksi DPRD akan berdampak pada terhambatnya kebijakan. Hal ini dilakukan oleh Pemerintah Daerah untuk menjaga kestabilan Pemerintahan Daerah. Pemerintah Daerah sebagai pemangku kewenangan dalam perumusan APBD 2017 mengakomodir kepentingan DPRD.

Masalah terlambatnya penyerahan KUA-PPAS mengakibatkan terjadinya keterlambatan pula pada penyusunan dan pembahasan RKA-SKPD dan RKA -PPKD serta penyusunan rancangan APBD. Proses ini seharusnya berlansung dari bulan agustus hingga September. Dari hasil wawancara yang didapat dari beberapa sumber, DPRD meminta bupati melakukan peninjauan ulang terhadap kinerja TPAD dalam Menyusun KUA-PPAS. Di lain hal, bupati menyatakan keterlambatan ini dikarenakan belum adanya RPJPD dan RPJMD kabupaten Kuantan singing yang kemudian akan digunakan dalam perumusan RAPBD. 


\section{Tipe Non-Decision Making}

Tipe non-decision making adalah interaksi yang diidentifikasi adanya kelompok yang kuat atau mayoritas berupaya mempengaruhi kebijakan. Interkasi tipe ini juga dapat melibatkan pihak ketiga atau eksternal untuk mendukung salah satu aktor keputusan. Pola interaksi yang digunakan adalah penyebaran isu publik, isu kelompok kepentingan untuk mendukung atau menentang proses penyusunan anggaran.

Dalam perumusan APBD 2017 Kabupaten Kuantan Singingi terjadi pertentangan alasan dan tudingan antara Pemerintah Daerah dan DPRD. Beberapa DPRD dari hasil wawancara yang mayoritas dari partai oposisi menyampaikan pendapat Pemerintah Daerah belum menyerahkan KUA-PPAS tanpa menjelaskan isu penyebab terlambatnya penyerahan KUA-PPAS. Pernyataan yang diberikan anggota DPRD membuat timbulnya rasa ketidakpercayaan terhadap kinerja Pemerintah Daerah. Di lain hal bupati ketika diwawancara menyampaikan akan menyegerakan proses perumusan APBD 2017 Kuantan Singingi dengan mengikuti alur yang telah ada. Pertentangan pernyataan ini mengindikasikan bahwa anggota DPRD dari pihak oposisi dengan melibatkan kepentingan tertentu menggunakan penyebaran isu publik dalam proses penyusunan anggaran.

\section{Tipe Systemic}

Tipe systemic adalah interaksi yang tidak secara langsung dipengaruhi oleh sistem, seperti sistem politik, ekonomi, sosial. Hal ini diidentifikasi melalui perilaku elit pejabat yang berpihak terhadap dirinya sendiri. Pada tipe interaksi ini dalam proses perumusan APBD tidak terlepas dari kepentingan elit dan tuntutan dari berbagai kelompok kepentingan. Dalam perumusan APBD 2017 Kabupaten Kuantan Singingi yang terlambat, keterlibatan elit belum terlihat karena interaksi yang terjadi dipengaruhi oleh sistem politik yang mana dikarenakan hasil Pilkada Kabupaten Kuantan Singingi tahun 2015. Mayoritas anggota DPRD yang menjabat pada periode 2014-2019 berasal dari partai pengusung yang kalah pada pilkada tersebut. Hal ini mengindikasikan adanya dendam politik antara DPRD kepada Pemerintah Daerah 2016-2021.

Tipe interaksi yang menunjukkan hubungan antara Pemerintah Daerah dan DPRD Kabupaten Kuantan Singingi dalam perumusan APBD 2017 terlihat tidak baik pada tahap perumusan KUA-PPAS. Permsalahannya terletak pada terlambatnya penyerahan KUA-PPAS oleh Pemerintah Daerah kepada DPRD sehingga mengakibatkan terlambatnya pengesahan APBD 2017 Kabupaten Kuantan Singingi. Interaksi yang ada mengindikasikan hubungan yang tidak baik antara kepala daerah dan DPRD yang memberikan pernyataan menjatuhkan satu pihak sehingga terjadinya citra buruk serta mengakibatkan timbulnya ketidakpercayaan terhadap kemampuan Pemerintah Daerah dalam menyusun KUA-PPAS. Tipe interaksi yang terjadi adalah tipe non-decision making karena DPRD yang memiliki kewenangan yang besar dalam pengesahan APBD berusaha mempengaruhi penetapan kebijakan.

Hubungan yang kurang baik antara DPRD dan Pemerintah Daerah menyebabkan terjadinya hal-hal yang tidak produktif terlebih menyangkut bidang yang sangat sensitif yaitu keuangan. Jika dikaitkan dengan teori keagenan, pihak eksekutif dapat diidentifikasi sebagai agen sedangkan pihak legislatif sebagai principal, yang diantara keduanya telah terjadi kesepakatan atau pembuatan kontrak. Namun yang terjadi dalam penetapan APBD 2017 Kuantan Singingi, kesepakatan antara DPRD dan Pemerintah Daerah terjadi tidak tepat waktu sehingga menyebabkan permasalahan lainnya.

Masing-masing pihak melakukan tindakan opportunisitik untuk melancarkan kepentingannya sehingga komunikasi politik yang baik tidak terjadi. Pihak DPRD dan Pemerintah Daerah berusaha menunjukkan citra baik untuk mempertahankan kekuasaan di 
masa mendatang. Upaya yang dilakukan oleh kedua belah pihak untuk mewujudkan kepentingannya yaitu dengan menepati janji kampanye. Salah satu caranya yaitu mengakomodir pelaksanaanya dalam APBD.

Suasana perpolitikan yang telah usai dan masih hangat dalam pembicaraan setelah terjadi persaingan politik yang begitu sengit membuat wakil rakyat yang berasal dari partai oposisi berusaha menggoyahkan langkah awal Pemerintah Daerah untuk memulai pemerintahannya. Kekuatan yang sangat sedikit di legislatif membuat terjadinya benturan antara kedua lembaga tersebut. Komunikasi politik yang baik sehingga menghasilkan kinerja yang baik pula tidak terjadi. Kekuatan mayoritas membuat polemik dalam penetapan APBD Kuantan Singingi mulai dari tahun 2017 hingga 2020 menuai berbagai polemik dan pro-kontra.

\section{Simpulan}

Berdasarkan hasil penelitian yang telah di dilakukan dan dibahas, dapat di lihat hubungan antara Pemerintah Daerah dan DPRD Kabupaten Kuantan Singingi pada perumusan APBD 2017 Kabupaten Kuantan Singingi terjadi tipe interaksi non-decesional making. Tipe interaksi ini merupakan bentuk interkasi yang dipengaruhi oleh adanya kelompok mayoritas yang kuat dalam mempengaruhi proses perumusan APBD terutama pada penyerahan dan penyepakatan KUA-PPAS dengan memberikan isu publik sehingga terbentuk citra buruk. Hubungan yang tidak baik inilah yang mengakibatkan terlambatnya pengesahan APBD 2017 Kabupaten Kuantan Singingi. Apabila hubungan antara kedua pihak baik dan harmonis, maka APBD 2017 dapat diselesaikan tepat waktu. Interaksi yang terjadi yang menyebabkan terjadinya interaksi non-decisional making dipengaruhi pula oleh kelompok elit dari anggota DPRD yang mayoritas berasal dari oposisi. Hal ini membuat kondisi tetap panas dan benang kusut antara DPRD dan Pemerintah Daerah tidak bisa terurai. Citra masing-masing pihak-pun terbentuk di masyarakat setelah terjadi permasalahan ini. Komunikasi yang buruk mengakibatkan hubungan yang tidak baik sehingga menghambat proses pemerintahan.

\section{Referensi}

Amin, F. (2019). Penganggaran Di Pemerintahan Daerah: Dalam Perspektif Teoritis, Normative, Dan Empiris. Malang: UB Press

Annas, A. (2017). Interaksi Pengambilan Keputusan Dan Evaluasi Kebijakan. Makassar: Celebes Media Perkasa

Heryanto, G.G. (2018). Problematika Komunikasi Politik. Yogyakarta: Ircisod

KPU.go.id https://pilkada2015.kpu.go.id/kuantansingingikab

Kuansing kita.com. DPRD kesal draft KUA-PPAS belum diserahkan eksekutif. 27 januari 2017. Akses 11 mei 2020. http://www.kuansingkita.com/2017/01/27/dprd-kesal-draftkua-ppas-belum-juga-diserahkan-eksekutif/

Kuansing kita.com. DPRD kesal draft KUA-PPAS belum juga diserahkan eksekutif. 27 januari 2017. Akses 05 mei 2020 http://www.kuansingkita.com/2017/01/27/dprdkesal-draft-kua-ppas-belum-juga-diserahkan-eksekutif/

Kuansing terkini http://kuansingterkini.com/berita/detail/4625/2014/09/08/dilantik-ketua-pn,35-anggota-dprd-kuansing-periode-2014-2019-resmi-bertugas

Marno, W. (2017). Politik Anggaran Eksekutif Dan Legislatif Pada Pembahasan APBD Kabupaten Buru Selatan 2015. Jurnal Of Government. Vol. 2 No. 2, Juni 2017. 
Melki. (2018). Hubungan DPRD Dan Pemerintah Daerah Dalam Penetapan Anggaran Pendapatan Belanja Daerah. Soumatera Law Review. Vol. 1 No. 1, 2018.

Nawawi, J. (2015). Analisis Hubungan DPRD Dan Pemerintah Daerah Dalam Pembuatan Kebijakan Kemiskinan Di Provinsi Sulawesi Barat. Jurnal Ilmu Pemerintahan. Vol. 8, No. 1, Januari 2015.

Redaksi Great Publisher. (2009). Buku Pintar Politik: Sejarah, Pemerintahan, Dan Ketatanegaraan. Yogyakarta: Galangpressgroup

Riau mandiri.id. perselisihan pemkab dan DPRD mencair, APBD 2017 kuansing segera $\begin{array}{llllll}\text { disahkan. } & 19 & \text { april } 2017 . & \text { Akses } & 05 & \end{array}$ https://www.riaumandiri.id/read/detail/51461/perselisihan-pemkab-dan-dprdmencair,-apbd-2017-kuansing-segera-disahkan.html

Tangkilisan, H.N.S. (2005). Manajemen Publik. Jakarta: PT Grasindo

Wance, M. (2017). Pola Relasi Eksekutif Dan Legislatif Pada Penyusunan Legislasi Daerah : Studi Di Pembahasan APBD Kabupaten Buru Selatan. Journal Governance Dan Public Policy. Vol. 4 No.1 February 2017. 